doi:10.18575/msrs.sm.e.16.24 UDK 618.5-089.888.61 COBISS.RS-ID 6165272

\section{Caesarean Section - before and now}

\begin{abstract}
Introduction: Caesarean section (CS) is one of the most common obstetric surgeries and often it is the only method to save mother's life and life of the fetus in various pregnancy and delivery complications. Each obstetric surgery, especially CS, implies professional valuation of prognostic valid parameters, i.e. existence of an accurate indication. The aim of the paper is to get a retrospective review of Caesarean section, its evaluation in the sense of frequency, indications and risk for mother and fetus. Frequency of Caesarean section was analyzed retrospectively and it has been noted that it grew significantly in past decades, which could be recognized as a new trend in the world in almost all countries, especially in the last decade. According to information from the WHO for 2010, CS percentage is as follows: USA 30.3\%, Cuba 35.6\%, Italy $37.4 \%$ and Germany $27.8 \%$.

In the first 6 months of 2006, at the Clinic of Gynecology and Obstetrics of the University Clinical Centre of the Republic of Srpska, CS percentage was $20.54 \%$, whereas in the same period of 2016, CS percentage is $31.58 \%$. Nowadays, the World Health Organization suggests adoption of classification per Robson in order to decrease the CS percentage down to between 15\% and 25\%. This surgery carries certain risks; maternal mortality is 2-4 times higher while morbidity is 5-10 times higher after Caesarean section in comparison to vaginal delivery. Caesarean section is connected to lower risk of fetal traumas and this is one of the essential reasons affecting the selection of Caesarean section over vaginal delivery. Thanks to the development of modern perinatology and surgery techniques as well as development of modern anesthesia, maternal morbidity, and especially mortality, is reduced to minimum.
\end{abstract}

Key words: Caesarean section, incidence, indications, vaginal delivery.

(Scr Med 2016:47:148-152)

\section{Dragica Draganović, Dragica Jojić ${ }^{2}$ Jelena Todorović ${ }^{1}$}

${ }^{1}$ Clinic of Gynecology and

Obstetrics, University Clinical Centre of the Republic of Srpska

${ }_{2}^{2}$ Pediatric Clinic, University Clinical Centre of the Republic of Srpska

\author{
Contact address: \\ Dragica Draganović \\ Klinika za ginekologiju i akušerstvo \\ Univerzitetsi klinički centar \\ Republike Srpske \\ St. 12 beba bb, \\ 78 ooo Banja Luka \\ Republic of Srpska \\ Bosnia and Herzegovina \\ Telephone: +38765527880 \\ E-mail: \\ dragica.draganovic@hotmail.com
}

Submitted: September $14^{\text {th }}, 2016$ Accepted: September 30 ${ }^{\text {th }}, 2016$.

\section{Introduction}

Caesarean section (CS) is one of the most common obstetric surgeries, where we use cut through mother's abdominal wall and uterus to extract fetus, most often in late stages of pregnancy when there is a possibility for the fetus to survive, and it is often the only method to save mother's life in various pregnancy and delivery complications. Each obstetric surgery, especially CS, implies professional valuation of prognostic valid parameters, i.e. existence of an accurate indication. Surgery is performed with the aim of avoiding or removing supposed or diagnosed pathological state resulting from pregnancy or delivery. Caesarean section was and, undoubtedly, still is one of the most important obstetric surgeries, which, in certain situations, saves lives of mother or fetus, or both mother and fetus. ${ }^{1}$

\section{Caesarean section incidence}

The frequency of this obstetric surgery has grown extremely in the past decades, which could be recognized as a new trend in the world in almost all countries, especially in the last decade.

The percentage of CS in Great Britain grew from $12 \%$ to $29 \%$ during the period from 1990 to 2008 . According to 
information from the WHO for 2010, CS percentage is as follows: USA 30.3\%,Cuba 35.6\%, Italy 37.4\%, Germany $27.8 \%$, Spain 25\% and France 18.8\%. In 1973, the percentage of CS in Sweden was 5\%, while in 1990 it was $10.84 \%$, and it is one of rare countries, along with Norway (16.3\%), where growing trend of the CS percentage is not significantly increased. ${ }^{2}$ Lately, increase of CS has been noted in the country with the largest population, China, as high as $50 \%$. There is an extremely high CS percentage noted in Brazil, 50.1\%, whereas in some private clinics it goes up to $85 \%$. In Serbia, in 2010, the CS percentage was $24.3 \%$ and it has been constantly growing in the last two years and, and according to incomplete data, it is about $35 \% .^{3}$ According to the report by the WHO, about 18.5 million Caesarean sections are performed in the world. In $50.4 \%$ of the countries, CS percentage is over $15 \%$. WHO recommends that CS percentage is to be between 15 and $25 \%$ and that higher percentage has no justified grounds since it does not lead to a decrease in total perinatal mortality. It is necessary to calculate and find optimal model of expected CS percentage at the level of national obstetrician associations. $^{2}$

The incidence of Caesarean section (CS) and Apgar score (A/S) of the Caesarean section for the first 6 months of 2006 and the first 6 months of 2016 were analyzed at the Clinic of Gynecology and Obstetrics of the University Clinical Centre of the Republic of Srpska.

As for the first 6 months of 2006, CS percentage was $20.54 \%$, and in 2016, it was $31.58 \%$. Analyzing Apgar score at birth for CS, in first half of the year 2016, the percentage of children with lower Apgar score (1-3) is smaller (2.7\%) in comparison with the year 2006, when it was $3.2 \%$. Apgar score from 4 to 7 was found in $13.8 \%$ children in the first half of the year 2006, and in 2016, there were $6.9 \%$ children delivered by Caesarean section. (Table 1)

Table 1. The incidence of Caesarean section and Apgar score at the Clinic of Gynecology and Obstetrics of the University Clinical Centre Banja Luka for the period from 1.1.2006 to 30.6. 2006 and from 1.1.2016 to 30.6.2016

\begin{tabular}{ccc}
\hline Year & $\begin{array}{c}1.1 .2006 .- \\
\text { 30.6.2006. }\end{array}$ & $\begin{array}{c}1.1 .2016- \\
30.6 .2016\end{array}$ \\
\hline Total number of deliveries & 1329 & 1545 \\
\hline Caesarean section (CS) \% & 273 & 488 \\
& $(20.5 \%)$ & $(31.6 \%)$ \\
\hline Apgar Scor at birth (CS) & 9 & 13 \\
$1-3$ & $(3.2 \%)$ & $(2.7 \%)$ \\
\hline Apgar Scor at birth (CS) & 36 & 34 \\
$4-7$ & $(13.8 \%)$ & $(6.96 \%)$ \\
\hline Apgar Scor at birth (CS) & 228 & 441 \\
$8-10$ & $(83.5 \%)$ & $(90.3 \%)$ \\
\hline
\end{tabular}

Significant increase of number of Caesarean sections, both primary and repetitive (iterative), is a trend in the world, ${ }^{4-8}$ and reasons for this are not quite understandable. Some explanations could be summarized as follows:

- There is a growing number of primiparas and they are exposed to increased risk for Caesarean section.

- A woman delivers at late age nowadays, and, especially if it is primipara, then a woman is under an increased risk for CS.

- Increase of CS is directly connected to ever growing use of electronic fetal monitoring in modern times compared to fetal auscultation earlier, and more current discovering of fetal distress.

- Most of deliveries by pelvic presentation are performed by CS as prevention from fetal injuries.

- Delivery by vacuum and forceps is in decline in the world, which is one of the reasons for the increase of CS.

- There is an increase in induced deliveries,which statistically have higher CS percentage.

- There is an increase in obese people, hence pregnant women - obesity is modern times disease and increases risk for CS.

- Development of modern neonatology brings increase in abortions with preeclampsia, being final and permanent solution for mother or for fetus or for both, and is one of causes of CS increase in the world and of iatrogenic prematurity.

- There is an increase of planned (elective) CS due to new-non-obstetric indications (eye indications, various mother's chronic diseases, premature delivery, Caesarean section desired by mother, previous Caesarean section-one or more, fear from delivery pain and delivery outcome, forensic medicine aspect of delivery outcome -fear for mother and fetus risk).

\section{Caesarean section indications}

Caesarean section is obstetric surgery saving the health and lives of mothers and children, which justifies this surgery in the majority of indications. In our region, Caesarean section is performed on medically justified indications. There are several accepted classifications, and the most accepted is the one for absolute, relative and extended Caesarean section indications. Nowadays, the World Health Organization (WHO) suggests adoption of Robson classification in order to decrease $\mathrm{CD}$ percentage down to between $15 \%$ and $25 \% .^{5}$ 
According to Robson classification, pregnant women are classified in 10 groups. Pregnancy characteristics used in this classification are as follows: singleton or multiple pregnancies, nulliparous, multiparous, or multiparous with previous CS, head precedence, pelvic presentation or other abnormal mal-presentations, spontaneous or induced delivery, due or preterm delivery. Studies conducted so far have shown that more than $85 \%$ of all Caesarean section indications are: previous Caesarean section, fetal distress, distortion and abnormal fetal presentation. ${ }^{4}$

Wide use of cardiotocography have increased frequency of Caesarean sections due to earlier and more frequent discovery of fetal distress compared to the period of periodic auscultation of fetal heart tones. Pelvic presentation has significantly increased as CS indication, being the consequence of obstetrician's inexperience, lack of patience and pressure of wider social community.

The percentage of Caesarean section with pelvic presentation in 1970 was $11.6 \%$, whereas in 1978, it grew to $60.1 \%$.Twin pregnancy has extremely increased as indication for Caesarean section in the world and in our country. According to the literature data (ACOG) for 1995, Caesarean section percentage with twin pregnancy was $53 \%$, and in 2008 , it was $75 \%$ (even in head precedence it increased from $45 \%$ to $68 \%$ ). ${ }^{6-10}$ Increase of Caesarean section with twin pregnancies is also a consequence of a large number of pregnancies with in vitro fertilization pregnancies and sterility treatment, increased number of complications following twin pregnancy, delivery at later age, higher percentage of preterm delivery and pelvic presentation, as well as obstetrician's fear from possible complications at delivery since these are "two fetuses".

The highest trend of CS increase has lately been noted with the following: condition after CS, preterm delivery, pelvic presentation, twin pregnancy, diabetes mellitus and post term pregnancy. Study by Brennan from 2009, which analyzed 47402 Caesarean sections from 9 world centers, has come to the conclusion that there is an increase of the condition after CS as an indication from $51.4 \%$ to $80.79 \%$, nulliparous pelvic presentation from $69.9 \%$ to $98.6 \%$, twin pregnancy from $34.7 \%$ to $74.6 \%$, preterm delivery from $22.2 \%$ to $46.6 \% .7$ Following are the reasons: decreased risk from fetal injuries, fear of pain and uncertainty, protection of pelvic bottom muscles. What is certain is that planned CS upon mother's request should not be performed before 39th gestation week and without a proof of fetal lung maturity. Study by the American College of Obstetrics and Gynecologists from 2013 showed no significant difference in the outcome of planned vaginal delivery and planned CS upon mother's request. ${ }^{4}$

\section{Caesarean delivery risks}

Risks and complications of Caesarean section refer to mother and fetus. It is necessary to provide informed consent from mother with previously detailed explanation of pros and cons of the surgery intervention itself, which is applied with all surgery interventions nowadays. Generally, CS has higher percentage of surgery complications by mother for current and all the upcoming pregnancies compared to the vaginal delivery, and smaller degree of perennial injuries and disturbances of pelvic floor. ${ }^{4}$

\section{Maternal mortality and morbidity}

This operation is also followed by certain risks; maternal mortality was 2-4 times higher, and morbidity 5-10 times after Caesarean section in comparison to vaginal delivery. ${ }^{1}$ Thanks to the development of modern perinatology and surgery techniques as well as development of modern anesthesia, maternal morbidity, and mortality in special, has been reduced to minimum. Incidence of maternal mortality in developed countries of the world (USA) amounts to 13.3 for 100 ooo and with vaginal delivery it amounts to 3.6 for 100 ooo, whereas total maternal mortality amounts to $2.7 \% .{ }^{8}$ In Guise meta analysis from 2010, mother's death was reported 13 times for 100000 repeated elective CS compared to mortality of 4 for 100000 CS in trying vaginal delivery preceded by CS. ${ }^{4}$ In the study conducted in Canada during the period from 1991 to 2005, frequency of maternal complications is also significantly higher compared to vaginal delivery, where percentage of all listed complications in CS is obvious in comparison to vaginal delivery (Table 2). ${ }^{9}$

Table 2. Complications of Caesarean section and vaginal delivery

\begin{tabular}{ccc}
\hline Complications & $\begin{array}{c}\text { Caesarean } \\
\text { section n-46766 }\end{array}$ & $\begin{array}{c}\text { Vaginal } \\
\text { delivery n-2 } \\
292420\end{array}$ \\
\hline Global morbidity & $2.73 \%$ & $0.9 \%$ \\
\hline Hysterectomy & $0.09 \%$ & $0.01 \%$ \\
\hline Infection & $0.60 \%$ & $0.21 \%$ \\
\hline Eenous thromboembolisms & $0.06 \%$ & $0.03 \%$ \\
\hline Carly hematoma & $1.3 \%$ & $0.27 \%$ \\
\hline Canaesthetic complications & $0.19 \%$ & $0.04 \%$ \\
\hline
\end{tabular}

Study by Villar and associates from 2010 reported double higher number of maternal morbidity with CS compared to vaginal delivery.4 Generally, all CS complications are more common in conditions after one or more Caesarean sections, performed in line with study by Marschal from 2011 and Silver from 2006. 4

This conditioned the increase of attempts for probe vaginal delivery preceded by CS. To make the best decision about the way of delivery after one precedent Caesarean section, 
we need an exact risk evaluation and benefit from each delivery method. Special attention is paid to evaluation of scar quality of the previously performed Caesarean section, done by ultrasound, which decreases a risk of uterus rupture, being one of the most difficult complications. At the conference held in 2010, the National Institutes of Health tried to make consensus on long-term and shortterm benefits and side outcomes with trying probe vaginal delivery preceded by CS and vaginal delivery itself preceded by CS. ${ }^{10}$

\section{Fetal morbidity and mortality}

Caesarean section is connected to lower risk of fetal traumas and this is one of the essential reasons affecting the selection of Caesarean section over vaginal delivery. In Caesarean section, we have significantly lower percentage of fetal injuries and lethal outcomes, but also a higher number of respiratory disturbances compared to vaginal delivery. The most common complications are skin injuries- skin lacerations, clavicle fracture, injury of plexus brachialis and skull fracture as well as facial nerve paralysis. Although risks for physical injuries are lower in Caesarean section, analyses showed that it did not significantly affect neurological development of an infant. Incidence of neonatal convulsions and cerebral paralysis has not been significantly decreased, according to study by Muller from 2008, although the CS rate has significantly increased. ${ }^{4}$ Neonatal depressions are more common due to general anesthesia, respiratory distress with term children, and transitory tachypnea of newborn and fetus injuries during surgery. Simultaneously with CS increase trend in the world, there is a trend of diseases such as autoimmune, allergic (asthma, allergic rhinitis, atopic dermatitis), diabetes mellitus type1 and multiple sclerosis. It has been noted that nowadays these diseases have been more frequent in highly developed countries. This, exactly, was a base for development of several theories suggesting that environmental factors, excessively clean environment could affect occurrence of these diseases in early childhood, which has been confirmed by a large number of epidemiological studies. Studies by Bager from 2008 and Decker from 2011 suggest that children born in Caesarean delivery have an increased risk for development of disease in later life such as: allergic diseases, diabetes mellitus type 1, celiac disease, with assumption that this increased risk could be a consequence of a lack of contact with maternal vaginal and intestinal flora at birth, which could affect delivery and formation of their immune system..$^{11,12}$

\section{Cesarean delivery techniques}

It is known that surgery techniques vary and depend on surgeon, and, in our clinical work, we are governed by already learned operative technique. Decrease of morbidity is greatly affected by the knowledge of basic surgery principles and use of acknowledged surgery methods.
There is a trend in the world in the development of surgery techniques of Caesarean section both as for incision on skin and opening and closing cut on uterus.

\section{Conclusion}

Making decision on surgery completion of delivery regardless gestation has to be supported by valid and accurate indications, good preparation of patient and the team performing it, as well as multidisciplinary cooperation, just before, during and after surgery-Caesarean section. In the Republic of Srpska and surrounding regions there is a trend of increased Caesarean deliveries which did not provide expected decrease of total perinatal mortality. Although CS is a relatively safe surgery, we should never forget we are talking about a very serious surgical procedure.

\section{Reference}

1. Petronijević A, Petković S, Pervulov M, Vrzić S, Carski rez, Beograd 1998; str.9-20.

2. World Health Organization (2015) Caesrean sections should only be performed when medically necessary. WHO, Geneva.

3. Izvještaj Insituta za Javno zdravlje „Milan Jovanović Batut“ za 2010.godinu. Dr Mirjana Živković-Šulović, februar 2011.

4. Cunningham FG, Leveno KJ, Bloom LS, Spong CZ, Dashe JS, Hoffman LB, et al. Williams Obstretics, 24th edition, NewYork 2014; Sec.8:587-609.

5. Robson MS, Classification of caesarean sections. Fetal Matern Med.Rev 2001;12:23-39.

http://dx.doi.org/10.1017/So965539501000122

6. Bogdanović-Mladenović Z,Blizanačka trudnoća i carski rez. Zbornik radova 60 Ginekološko akušerska nedelja SLD, Beograd. 2016; 66-68.

7. Brennan DJ, Robson MS, Murphy M, O'Herlihy C. Comparative analysis of international caesarean delivery rates using 10-group classification identifies significant variation in spontaneous labor. Am J Obstet Gynecol. 2009;201(3):308.e1-8.

http://dx.doi.org/10.1016/j.ajog.2009.06.021

PMid:19733283

8. Deneux-Tharaux C, Carmona E, Bouvier-Cole MH, Breart G. Postpartum maternal mortality and cesarean delivery. ObstetGynecol. 2006; 108(3): 541-8. http://dx.doi.org/10.1097/01. AOG.0000233154.62729.24 PMid:16946213

9. Liu S, Liston RM Joseph KS, Heaman M, Sauve R, Kramer MS. Maternal mortality and severe morbidity associated with low-risk planned cesarea deliveryversus planned vaginal delivery at term. Maternal Health Stody Group of the Canadian Perinatal Surveillance System. CMAJ 2007, 176(4): 455-60.

http://dx.doi.org/10.1503/cmaj.060870

PMid:17296957 PMCid:PMC1800583

10. National Institutes of Health Consensus Development Conference Panel. National Institutes of Health Consensus Development conference statement: vaginal birth 
after cesarean: new insights March 8-10, 2010. Obstet Gynecol.2010;115:1279-95. http://dx.doi.org/10.1097/ AOG.obo13e3181e459e5 PMid:20502301

11. Bager P, Wohlfahrt J, Westergaard T. Caesarean delivery and risk of atopy and allergicdisease:meta-analysis. Clin EXP Allergy.2008;38(4);634-42. http://dx.doi.org/10.1111/

\section{j.1365-2222.2008.02939.x PMid:18266879}

12. Decker E, Englemann G, Findeisen A, et al. Cesarean delivery is associated with celiac disease but not inflammatory bowel disease in children. Pediatrics. 2010;125(6):e1433-40. http://dx.doi.org/10.1542/peds.2009-2260 PMid:20478942

\section{Carski rez - prije i sada}

\section{SAŽETAK}

Carski rez (CS) predstavlja jednu od najčešćih akušerskih operacija i često je jedina metoda kojom se može spasiti život majke i ploda kod raznih komplikacija trudnoće i porođaja. Svaka akušerska operacija, a pogotovo CS, podrazumijeva stručno vrednovanje prognostičkih validnih parametara, odnosno postojanje tačne indikacije. Cilj rada je da se retrospektivno sagleda carski rez, njegova evaluacija u pogledu učestalosti, indikacija i rizika po majku i plod. Retrospektivno je analizirana učestalost carskog reza i uočeno je da je u posljednjim decenijama u velikom porastu, što se može nazvati novijim trendom u svijetu u skoro svim državama, a naročito u posljednjih deset godina. Prema podacima SZO za 2010. godinu, procenat CS u navedenim zemljama je: SAD 30,3\%, Kuba 35,6\%, Italija 37,4\%, Njemačka 27,8\%. Na Klinici za ginekologiju i akušerstvo UKC RS, u prvih 6 mjeseci 2006. godine, procenat CS iznosio je 20,54\%, dok u istom periodu 2016. godine procenat SC iznosi 31,58\%. Danas Svjetska zdravstvena organizacija predlaže usvajanje klasifikacije po Robsonu, kako bi se procenat CS smanjio između 15\% i 25\%. Ova operacija nosi i određene rizike; maternalni mortalitet je 2-4 puta veći, dok je morbiditet 5-10 puta veći poslije carskog reza u poređenju sa vaginalnim porođajem. Carski rez je povezan sa nižim rizikom od fetalnih trauma i to je jedan od ključnih razloga koji utiču na izbor za carski rez u odnosu na vaginalni porođaj. Zahvaljujući razvoju savremene perinatologije i operativnih tehnika, kao i razvoju savremene anestezije, maternalni morbiditet, a pogotovo mortalitet, je sveden na minimum.

Ključne riječi: carski rez, incidencija, indikacije, vaginalni porođaj. 